\title{
THE EFFECT OF MENTAL WORKLOAD TO THE NURSE'S BURNOUT LEVEL IN THE PRIVATE HOSPITALS
}

\author{
Yesiana Dwi Wahyu Werdani \\ Faculty of Nursing Widya Mandala Catholic University Surabaya, Indonesia \\ Email: ywerdani@yahoo.com
}

\begin{abstract}
Nurse is a part of professional health care that provides nursing care to patient and family. Nurses must do their job quickly, precisely, and without mistakes. The high demand of nurse's job can lead mental workload. Mental workload that not managed properly will lead to burnout condition. This study aimed to analyze the effect of mental workload to the nurse's burnout level. This study was cross-sectional. The population was in-patient nurses in three private hospitals. The number of participants was 89 nurses taken by proportionate stratified random sampling. The instruments were questionnaire of the mental workload from NASA-TLX and Maslach Burnout Inventory. Data were analyzed by ordinal regression test with $p<$ 0.05. The effect of mental workload to the nurse's burnout level on the emotional exhaustion sub-scales was 0.001 , depersonalization was 0.008 , and personal accomplishment was 0.003. It concluded that there was an effect of mental workload to the nurse's burnout level. The high of mental workload could be due to high number of Bed Occupation Rate and total care level of dependence. The mental workload has an impact on the nurse's burnout on the three subscales.
\end{abstract}

Keywords - mental workload, nurse, burnout level

\section{INTRODUCTION}

Nurse is a part of professional health team in the global era. It need efforts to be a professional nurse to provide the nursing care to patients and family. Nurses must do the nursing care quickly, precisely and without any mistakes. The nurse's jobs have a lot of high risk. It tends to make a mental workload for nurses when carried out its duties and functions daily. Mental workload is a fundamental factor of performance (work, cognitive and psychological aspects)[1]. If it's not managed properly could lead to the nurse's burnout and reduced nurses performance.

The previous study as in [2] said that mental workload influence the performance of worker. Based on results of the initial survey in November 2014, there were three private hospitals in Surabaya that never evaluated the nurse's mental workload and burnout. The in-patient rooms had a high number of patients, and patients have many demands to be fulfilled. Every hospital has a total number of nurses 116 people, and the number of patients treated per month was 430 patients.

As well as the research as in[3] to the surgical nurses, eye nurses, medical nurses and neurology nurses in the $\mathrm{XYZ}$ hospitals, it concluded that all nurses had the high level of mental workload with the dominant factor was the dimensions of physical demand. Ref [4] also did research about burnout to nurses at in-patient and out-patient unit of Harapan Kita Hospital. The research results that nurse's burnout at outpatient unit was higher than the in-patient unit.

Nurse requires concentration and skills to provide the nursing care because an error treatment can be dangerous for patient's safety. Problem among nurses such as interpersonal conflicts also can lead to job stress. When job stress occurs in a period of time, the nurse could get the mental workload. The nurse should managed mental workload properly because it could lead to burnout condition. This study was aimed to analyze of how much the effect of mental workload to the nurse's burnout level.

\section{METHOD}

This study was a correlational study with cross-sectional approach[5]. It analyzed the causal relationships between independent and dependent variable.

The population was nurses of in-patient unit in private hospital A, B, and C in Surabaya. The number of participants was 89 nurses, taken by proportionate stratified random sampling technique.

Independent variable was mental workload and dependent variable was the nurse's burnout level.

This study used two instruments. The first instrument was NASA-Task Load Index (NASA-TLX) for measuring the mental workload. It consists of six dimensions: mental demand, physical demand, temporal demand, performance, effort, and frustration[6]. The second instrument was Maslach Burnout Inventory that measured the nurse's burnout level. It consist of three aspect: emotional exhaustion, depersonalization, and personal accomplishment.

Instruments was tested statistically for validity and reliability in 20 nurses. The result proved that NASA-TLX was valid and reliable by value of $r=1-0.746, \alpha=0.902$. The result of Maslach Burnout Inventory was valid and reliable by result $r=0.927-0.414, \alpha=0.963$.

Data was analyzed by ordinal regression $\alpha \leq 0.05$. Ethical concern on informed consent, anonymity, and confidentiality. 


\section{RESULT}

TABLE I. DEMOGRAPHIC CHARACTERISTIC OF HOSPITAL A, B, C, SURABAYA, APRIL 2015

\begin{tabular}{|c|c|}
\hline Demographic characteristic & Result \\
\hline The average of Bed Occupation Rate (BOR) & $\mathbf{8 0 \%}$ \\
\hline $\begin{array}{c}\text { The average number of patients treated by one } \\
\text { nurse }\end{array}$ & 4-5 patients \\
\hline The average of patient's level dependence total care & $35.5 \%$ \\
\hline $\begin{array}{c}\text { The average of patient's level dependence partial } \\
\text { care }\end{array}$ & $32.8 \%$ \\
\hline $\begin{array}{c}\text { The average of patient's level dependence minimal } \\
\text { care }\end{array}$ & $31.7 \%$ \\
\hline The average Length of Stay (ALOS) & $4-6$ days \\
\hline
\end{tabular}

TABLE II. DEMOGRAPHIC CHARACTERISTIC OF PARTICIPANTS IN THE HoSPITAL A, B, C, SURABAYA, APRIL 2015

\begin{tabular}{|c|c|c|c|}
\hline Data & Category & $\begin{array}{c}\text { Frequen } \\
\text { cy }\end{array}$ & $\begin{array}{c}\text { Perc } \\
\text { ent } \\
(\%)\end{array}$ \\
\hline \multirow[t]{2}{*}{ Age } & Middle Adult ( 20 - 40 years old $)$ & 78 & 87.6 \\
\hline & Late Adult (> 40 years old) & 11 & 12.4 \\
\hline Sex & Female & 89 & 100 \\
\hline \multirow[t]{2}{*}{ Marital State } & Unmarried/single & 24 & 27.0 \\
\hline & Married & 65 & 73.0 \\
\hline \multirow{3}{*}{$\begin{array}{c}\text { Length of } \\
\text { working }\end{array}$} & $<5$ years & 39 & 43.8 \\
\hline & $5-10$ years & 22 & 24.7 \\
\hline & $>10$ years & 28 & 31.5 \\
\hline \multirow{3}{*}{$\begin{array}{l}\text { Education } \\
\text { background }\end{array}$} & Nursing School & 2 & 2.2 \\
\hline & Nursing Diploma & 77 & 86.5 \\
\hline & Bachelor of Nursing & 10 & 11.2 \\
\hline
\end{tabular}

TABLE III. THE MENTAL WORKLOAD OF PARTICIPANTS IN THE HOSPITAL A, B, C, SURABAYA, APRIL 2015

\begin{tabular}{ccc}
\hline $\begin{array}{c}\text { Level of mental } \\
\text { workload }\end{array}$ & Frequency & Percent (\%) \\
\hline The highest level & 47 & 53 \\
\hline High level & 33 & 37 \\
\hline Moderate level & 8 & 9 \\
\hline Low level & 1 & 1 \\
\hline
\end{tabular}

TABLE IV. THE MENTAL WORKLOAD DIMENSION OF PARTICIPANTS IN THE hOSPITAL A, B, C, SURABAYA, APRIL 2015

\begin{tabular}{cc}
\hline Mental Workload Dimension & Percent(\%) \\
\hline Physical Demand & 10 \\
\hline Mental Demand & 4 \\
\hline Temporal Demand & 10 \\
\hline Performance & 29 \\
\hline Effort & 38 \\
\hline Frustration & 9
\end{tabular}

TABLE V. CROSSTABULATION BETWEEN THE MENTAL WORKLOAD AND THE NURSE'S BURNOUT LEVEL ON EMOTIONAL EXHAUSTION SUB-SCALE IN THE HOSPITAL A, B, C, SURABAYA, APRIL 2015

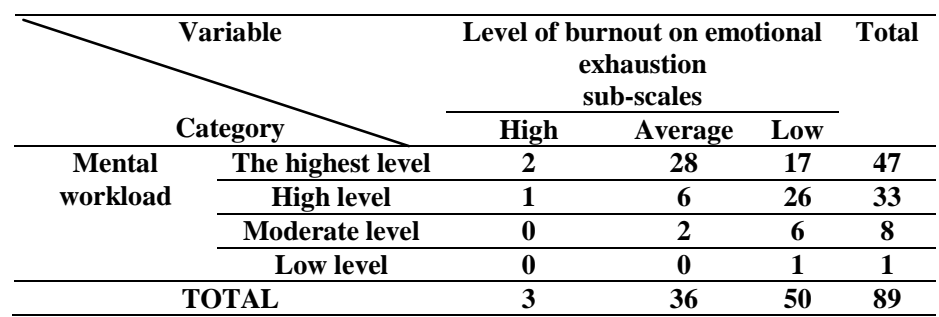

TABLE VI. CROSSTABULATION BETWEEN THE MENTAL WORKLOAD AND THE NURSE'S BURNOUT LEVEL ON DEPERSONALIZATION SUB-SCALES IN THE HOSPITAL A, B, C, SURABAYA, APRIL 2015

\begin{tabular}{|c|c|c|c|c|c|}
\hline \multirow{2}{*}{\multicolumn{2}{|c|}{ Variable }} & \multicolumn{3}{|c|}{$\begin{array}{c}\text { Level of burnout on } \\
\text { depersonalization sub-scales }\end{array}$} & \multirow[t]{2}{*}{ Total } \\
\hline & & High & Average & Low & \\
\hline \multirow[t]{4}{*}{$\begin{array}{c}\text { Mental } \\
\text { workload }\end{array}$} & $\begin{array}{c}\text { The highest } \\
\text { level }\end{array}$ & 10 & 33 & 4 & 47 \\
\hline & High level & 1 & 22 & 10 & 33 \\
\hline & $\begin{array}{c}\text { Moderate } \\
\text { level }\end{array}$ & 2 & 4 & 2 & 8 \\
\hline & Low level & $\mathbf{0}$ & $\mathbf{0}$ & 1 & 1 \\
\hline \multicolumn{2}{|c|}{ TOTAL } & 13 & 59 & 17 & 89 \\
\hline
\end{tabular}

TABLE VII. CROSSTABULATION BETWEEN THE MENTAL WORKLOAD AND THE NURSE'S BURNOUT LEVEL ON PERSONAL ACCOMPLISHMENT SUB-SCALES IN THE HOSPITAL A, B, C, SURABAYA, APRIL 2015

\begin{tabular}{|c|c|c|c|c|c|}
\hline \multirow{2}{*}{\multicolumn{2}{|c|}{ Category }} & \multicolumn{3}{|c|}{$\begin{array}{c}\text { Level of burnout on personal } \\
\text { accomplishment } \\
\text { sub-scales }\end{array}$} & \multirow[t]{2}{*}{ Total } \\
\hline & & High & Average & Low & \\
\hline \multirow{5}{*}{$\begin{array}{c}\text { Mental } \\
\text { workload }\end{array}$} & The highest level & 5 & 33 & 9 & 47 \\
\hline & High level & 5 & 28 & 0 & 33 \\
\hline & Moderate level & 5 & 2 & 1 & 8 \\
\hline & Low level & $\mathbf{0}$ & 1 & 0 & 1 \\
\hline & TOTAL & 15 & 64 & 10 & 89 \\
\hline
\end{tabular}

TABLE VIII. THE RESULTS OF HYPOTHESIS TESTING BETWEEN THE MENTAL WORKLOAD AND THE NURSE'S BURNOUT LEVEL IN THE HOSPITAL A, B, C, SURABAYA, APRIL 2015

\begin{tabular}{cccc}
\hline & Variable & Significance & Coefficient \\
\hline Independent & Mental Workload & & \\
\hline Dependent & $\begin{array}{c}\text { Level of burnout on } \\
\text { emotional exhaustion sub- } \\
\text { scales }\end{array}$ & $\mathbf{0 . 0 0 1}$ & $\mathbf{0 . 0 9 8}$ \\
\cline { 2 - 4 } & $\begin{array}{c}\text { Level of burnout on } \\
\text { depersonalization sub- } \\
\text { scales }\end{array}$ & $\mathbf{0 . 0 0 8}$ & $\mathbf{0 . 0 4 6}$ \\
\cline { 2 - 3 } & $\begin{array}{c}\text { Level of burnout on } \\
\text { personal accomplishment } \\
\text { sub-scales }\end{array}$ & $\mathbf{0 . 0 0 3}$ & $\mathbf{0 . 0 6 5}$ \\
\hline
\end{tabular}

The result showed that in the hospital A, B, C in in-patient unit had the average of BOR by number $80 \%$. Each nurse handled 4-5 patients. The highest of average patient's level dependence was total care $(35.5 \%)$, the average length of stay 4-6 days. The patient characteristic was predominance by middle-adult age $(87.6 \%)$. All of the participants was female with married status (73\%). Based on the year of service, most participants has been working less than 5 years $(43.8 \%)$. But most of the nurse's education background was nursing diploma $(86.5 \%)$.

Mental workload level predominance by highest level $(53 \%)$ and the least was low level $(1 \%)$. The mental workload dimension that affected was effort (38\%). The nurse characteristic of mental workload predominance by nurses with highest level of mental workload and had the average level of burnout on emotional sub-scales (28 participants). 
Table 6 showed that the most condition was nurses with the highest level of mental workload and had the average level of burnout on depersonalization sub-scales (33 participants). The condition of nurses with the highest level of mental workload had the average level of burnout on personal accomplishment (33 participants). According to the table 8 showed that the significance of mental workload to the level of burnout on emotional exhaustion sub-scales was 0.001, to the level of burnout on depersonalization sub-scales was 0.008 , and to the level of burnout on personal accomplishment sub-scales was 0.003 . It means that the mental workload affected the level of burnout on the three sub-scales.

\section{DISCUSSION}

There are three internal factors affected the workload of nurses; the number of patients treated, the patient's level dependence, and Length Of Stay (ALOS)[7].

This study found that mental workload predominance by highest level (52.8\%). That situation might be caused by high percentage of BOR $80 \%$ in hospital, and the patient's level dependency was total care $(35.5 \%)$. Total care is a condition that the patient requires full assistance of nurses, the appearance of the patient is severely ill, required observation continuously, and had unstable condition.

The high percentage of BOR and patient dependency level was total care caused the activity of nursing care was very high too[8]. The nurse must interact with patients consistently and provide the nursing care directly and indirectly. The nurse had less time to take a rest on their duty. It made them tired physically. Moreover every nurse must taking care 4-5 patients per day with the ALOS 4-6 days. Every patient had different basic human needs and the nurse must full-filled it well and without any mistakes. That situation could lead to mental workload for nurses.

The results of this study was consistent with the study as in [3], it concluded that nurses on duty at out-patients (surgical unit, eye unit, physiotherapy, internist unit, neurological unit) had the high level of mental workload.

This study also found that the most mental workload dimension was effort dimension $(38.2 \%)$. It is an activity that combine the physic and mental to complete the job. It occurred because nurses in the three private hospital had responsibility to provide the nursing care to the patients and family optimally, so nurses provided all of physical power and mental effort to achieve it. Ref [9] declare that effort dimension consist of mental activity and physical activity. Mental activity for the nurse is an ability to do something through five senses; a nurse has to think, remember, analyze, make a decision and conclude. When nurses arrange the nursing process comprehensively, they must do an assessment and physical examination through their five senses. Nurses also analyze the nursing diagnosis, use the critical thinking to arrange the intervention, and make a decision to implement the intervention carefully. While physical activity for the nurse is a physical ability to support the providing of nursing care, it includes an ability to walking, running, pushing, up and down stairs. These activities stimulate the releasing of physical energy that caused physical fatigue; it may further have an impact on mental exhaustion.

This study found that all of participants had burnout on the different level. On emotional exhaustion sub-scales achieved the low level $(56.2 \%)$, on the depersonalization sub-scales achieved the average level $(66.3 \%)$ and on the personal accomplishment achieved the average level (71.9\%). This study was consistent with the study as in [4] that concluded that nurses at in-patient unit in RSAB Harapan Kita had the high level of burnout on personal accomplishment sub-scales. Ref [10] explained that job stress that experienced by nurses could cause by job complexity, nurse's workload, reward, and punishment system.

This study found that most level of burnout experienced by nurses was average level. It occurred on depersonalization subscale and personal accomplishment subscale. It happened because nurses had the highest level of mental workload. However, nurses still had the high dedication to provide the nursing care to patients and family, so the level of burnout achieve on the average level.

Person that had a burnout would experience emotional changes as the first encounter. That could lead to personality and work performance changes[11]. This study result showed emotional exhaustion had low level than depersonalization and personal accomplishment subscale. The possible reason of it was that $100 \%$ participants were women and Javanese ethnic. Characteristic of Javanese ethnic is polite and not vulgar in expressing something negative. Furthermore, the most participants were middle-adult. The characteristic of middle age that individuals have a tendency to arranging the career and doesn't want to make the problem on the job. Individuals have the maturity on thinking and acting[12].

The study showed that statistic testing significance of the mental workload of burnout level on emotional exhaustion was 0.001 , on depersonalization was 0.008 and on personal accomplishment was 0.003 . It means that the mental workload affected to the nurse's burnout level on the three of subscales. This study was consistent with the research as in [13], it concluded that there was a significant relationship between job stress and nurse's burnout in Emergency Department and Intensive Care Unit with the significance result 0.000 .

Ref [14] said that burnout occurs by working and housing situation. Most people said that burnout occurred because of an overload of working. The occupation that can lead to burnout is the job that makes people feel less adequate control, less reward on the excellent results, job with excessive workloads, doing tedious work and job with no challenges.

\section{CONCLUSION}

Based on the result of this study was concluded that nurses on duty in inpatient unit had the highest level of mental workload and it affected to the burnout on the low level of emotion exhaustion sub-scales, on the average level of depersonalisation and personal accomplishment sub-scales.

Based on the result of this study, the researcher suggested that management of hospital has to create a modification of 
personal activity to nurses (example: family gathering, a forum of discussion between the management team and staff, nursing award).

\section{References}

[1] A. J. Byrne, A. Murphy, O. McIntyre, and N. Tweed, "The relationship between experience and mental workload in anesthetic practice: an observational study," Anaesthesia, vol. 68, pp. 1266-1272, 2013.

[2] H. Sato, T. Miyashita, H. Kawakami, Y. Nagamine, S. Takaki, and T. Goto, "Influence of Mental Workload on the Performance of Anesthesiologists during Induction of General Anesthesia: A Patient Simulator Study,” Biomed Res. Int., vol. 2016, 2016.

[3] T. Hidayat, S. Pujangkoro, and Anizar, "Pengukuran Beban Kerja Perawat Menggunakan Metode NASA-TLX di Rumah Sakit XYZ," J. Tek. Ind. FT USU, vol. 2, no. 1, 2013.

[4] S. Mariyanti and A. Citrawati, "Burnout Pada Perawat Yang Bertugas di Ruang Rawat Inap dan Rawat Jalan RSAB Harapan Kita," J. Psikol., vol. 9, no. 2, 2011.

[5] Johnson and Christensen, Educational Research Fourth Edition; Quantitave, Qualitative, and Mixed Approached. India: Sage Publication Inc., 2010.
[6] A. Cao, K. Chintamani, A. Pandya, and R. Ellis, "NASA TLX: Software for assessing subjective mental workload," Behav. Res. Methods, vol. 41, no. 1, pp. 113-117, 2009.

[7] A. Kurniadi, Manajemen Keperawatan dan Prospektifnya; Teori, Konsep dan Aplikasi. Jakarta: Balai Penerbit Fakultas Kedokteran Universitas Indonesia, 2013.

[8] Nursalam, Manajemen Keperawatan; Aplikasi dalam Praktik Keperawatan Profesional. Jakarta: Salemba Medika, 2014.

[9] S. Miller, Literature Review Workload Measures. Iowa: The University of Iowa, 2001.

[10] D. Whitebeard, S. Weiss, and R. Tappen, Essential of Nursing Leadership and Management, Fifth edit. Philadephia: F.A. Davis Company, 2010.

[11] R. Elder, K. Evans, and D. Nizette, Psychiatric and Mental Health Nursing, 3rd ed. USA: Elsevier, 2012.

[12] Tim Pengembang Ilmu Pendidikan, Ilmu dan Aplikasi Pendidikan. Jakarta: PT Imtima, 2007.

[13] N. Prestiana and D. Purbandini, "Hubungan Antara Efikasi Diri (Self Efficacy) Dan Stress Kerja Dengan Kejenuhan Kerja (Burnout) Pada Perawat IGD dan ICU RSUD Kota Bekas,” J. Soul, vol. 5, no. 2, 2012.

[14] H. Warner, Stress, Burnout, And Addiction in The Nursing Profession. USA, 2014. 